\title{
Biotilsvarende legemidler ved inflammatorisk tarmsykdom
}

\author{
Behandling av ulcerøs kolitt og Crohns sykdom med biologiske legemidler er vanligvis effektivt, men kost- \\ bart. Patentet på det første medikamentet som kom på markedet, har utløpt, og et mye billigere, biotilsva- \\ rende medikament er nylig blitt registrert.
}

Dette nye medikamentet anbefales nå som førstevalg av Legemiddelinnkjøpssamarbeidet, men vi mener det er grunn til tilbakeholdenhet før flere studier av det nye medikamentet er gjennomført.

Monoklonale, terapeutiske antistoffer til medisinsk bruk kalles biologiske legemidler. Fremstillingen er vanskelig og baseres på biologiske prosesser der antistoffene produseres i genetisk modifiserte cellekolonier, med de utfordringer dette innebærer.

Når legemiddelprodusenter vil lage «kopier» av eksisterende medikamenter, må kopiprodusenten utvikle egne cellekolonier og lage syntetiske gener som koder for et protein som er så likt det opprinnelige som mulig. En slik prosess vil aldri kunne gi helt identisk resultat med originalmedikamentet, og derfor kalles disse kopiene ikke generiske medikamenter, men «biotilsvarende» medikamenter. Produktene av denne prosessen testes biokjemisk og klinisk i samarbeid med det europeiske legemiddelverket (The European Medicines Agency - EMA) etter egne retningslinjer (1).

De biotilsvarende medikamentene skal vise tilsvarende effekt og ha samme sikkerhetsprofil som det preparatet de har «etterliknet». Det debatteres om effekten skal vises hos alle sykdommer der det opprinnelige preparatet har vist seg effektivt, eller om man skal nøye seg med å vise effekt ved én eller noen få sykdommer, og deretter ekstrapolere til andre. Argumentet for ekstrapolering er at millioner av kroner i utviklingsomkostninger kan spares $(1,2)$. Sluttresultatet blir at medikamentene kan tilbys til en betydelig redusert pris - noe som selvsagt vil være ønskelig.

\section{Nye anbefalinger}

Frem til nå har behandlingsalternativene med biologiske legemidler for pasienter med ulcerøs kolitt og Crohns sykdom vært infusjon med infliksimab (Remicade, fra MSD), subkutan injeksjon av adalimumab (Humira, fra Abbvie) eller golimumab (Simponi, fra MSD), sistnevnte kun til pasienter med ulcerøs kolitt.

Infusjonsbehandling må skje på sykehus, mens subkutane injeksjoner kan administreres av pasienten selv. Effekten av disse behandlingsalternativene anses likeverdig, og Legemiddelinnkjøpssamarbeidet har tidligere kommet med anbefalinger om at det billigste alternativet bør være førstevalg (3).
Imidlertid har kostnadene ved behandlingsalternativene vært såpass like at det ut fra vår erfaring $\mathrm{i}$ stor grad har vært individuelle preferanser og administrasjonsform som har vært avgjørende for hva man har valgt. Patentet på infliksimab utløp nylig, og det har nå kommet biotilsvarende medikamenter til dette på markedet.

I januar ble Legemiddelinnkjøpssamarbeidets anbefaling vedrørende biologiske medikamenter innen gastroenterologi for

\section{«Det mangler god dokumentasjon for bruk av biotilsvarende medikamenter ved ulcerøs kolitt og Crohns sykdom»}

2014 bekjentgjort (4). To biotilsvarende medikamenter til infliksimab (Remicade) var med i anbudsrunden: Remsima (fra OrionPharma) og Inflectra (fra Hospira).

Legemiddelinnkjøpssamarbeidet anbefaler nå Remsima som førstevalg ved biologisk behandling av ulcerøs kolitt og Crohns sykdom. Prisen ligger 39\% under Remicades prisnivå fra 2013. I rene medikamentutgifter vil dette for første års behandling av én pasient bety en besparelse på ca. 50000 kroner. Tilsvarende besparelse sammenliknet med bruk av Humira vil være ca. 40000 kroner (4).

Alternativene blir altså ansett som likeverdige av Legemiddelinnkjøpssamarbeidet med tanke på effekt og bivirkninger, og derfor blir det pris og administrasjonsmåte som vil ha betydning for valg av preparat. Bruk av Humira, som administreres subkutant, har vridd behandling og kontroll over til poliklinikken i spesialisthelsetjenesten. Remsima er nå det klart billigste alternativet, og dette som førstevalg vil medføre en betydelig besparelse i medikamentkostnad. Samtidig administreres Remsima som infusjon, og en økt bruk vil derfor også medføre at flere pasienter må inn på sykehus for å få behandlingen, og følgelig vil det føre til økt ressursbruk på infusjonspoliklinikkene. Den reelle kostnadsbesparelsen vil dermed ikke bli like stor som prisforskjellen i direkte medikamentkostnad.

\section{Hva blir konsekvensen?}

For dem som starter med biologisk behandling for første gang, vil det billigste alternativet nå være infusjon med Remsima. Den økonomiske besparelsen ved å velge Remsima vil gjøre det nærliggende å velge dette. Da må man også akseptere en viss usikkerhet, da virkningen av Remsima ved Crohns sykdom og ulcerøs kolitt ikke er dokumentert i randomiserte studier. Pasienten bør også tas med på avgjørelsen om behandlingsvalg og administrasjonsform. Sist vil også spørsmålet om behandlingskapasitet på sykehusets infusjonspoliklinikk kunne være avgjørende for valget.

Fra et medisinskfaglig ståsted vil spørsmålet om de som allerede står på en velfungerende behandling med Remicade, skal bytte til et mye billigere biotilsvarende alternativ, være mye mer problematisk. Vi vil sterkt fraråde dette nå, da biotilsvarende ikke er synonymt med bioidentisk, og fordi det per i dag er usikkert hvilke konsekvenser et bytte kan få. Man kan tenke seg tap av primæreffekt og antistoffutvikling med alvorlige infusjonsreaksjoner som mulige bivirkninger. På grunn av manglende dokumentasjon av effekt og sikkerhet ved bytte mellom biotilsvarende legemidler, er det avsatt en ekstrabevilgning i statsbudsjettet på 20 millioner kroner til en utprøvende studie for fagområdene revmatologi, gastroenterologi og hudsykdommer. Vi mener at den naturlige konsekvensen av dette er at ingen pasienter med inflammatorisk tarmsykdom bør bytte til et biotilsvarende medikament før pasienten har fått tilbud om å delta i den planlagte byttestudien. Bytte til biotilsvarende medikament der Remicade har tapt effekt eller det har oppstått bivirkninger, er også høyst betenkelig, da det må forventes samme effekt og bivirkningsprofil etter byttet. Derimot vil bytte på grunn av manglende effekt eller bivirkninger fra Humira eller Simponi til Remsima anses som et alternativ, hvor vi inntil nå har forsøkt Remicade.

Oppsummert mener vi at det mangler god dokumentasjon for bruk av biotilsvarende medikamenter ved ulcerøs kolitt og Crohns sykdom. Dette skaper usikkerhet hos nasjonale og internasjonale helsepoli- 
tiske beslutningstakere og i fagmiljøene.

Uavklarte spørsmål omkring effekt og sikkerhet er fagmiljøenes store bekymring, og det trengs nye studier for å få avklart dette. Norske myndigheter har bevilget flere titalls millioner kroner for dette formålet. Det hadde vært ønskelig med en slik avklaring før Legemiddelinnkjøpssamarbeidet gikk ut med sine anbefalinger.

Avgjørelsen for når det skal velges biotilsvarende medikamenter er nå lagt på den enkelte spesialist og sykehusledelse, med det ansvar som følger. I fravær av en felles beslutningsarena for faglig holdning til bytte, registre som kan følge pasientene og oppstart av en studie som fordrer at pasienter på etablert behandling kan skifte under nøye kontroll, mener vi at det bør legges opp til en skeptisk, konservativ tilnærming fra oss spesialister.

Bjørn Moum

bjorn.moum@medisin.uio.no

Knut E.A. Lundin

Bjørn Moum (f. 1952) er professor og overlege ved Gastromedisinsk avdeling, Oslo universitetssykehus.

Forfatter har fylt ut ICMJE-skjemaet og oppgir følgende interessekonflikter: Han har mottatt honorar fra Abbvie, MSD, OrionPharma, Hospira, TakedaNycomed, Ferring, Tillotts, Meda, Pharmacosmos og ViforPharma.

Knut E.A. Lundin (f. 1958) er førsteamanuensis og overlege ved Oslo universitetssykehus, Rikshospitalet.

Forfatter har fylt ut ICMJE-skjemaet og oppgir følgende interessekonflikter: Han har mottatt honorar fra Abbvie, MSD, OrionPharma, Hospira, TakedaNycomed, Meda, Regeneron og GlaxoSmithKline.

\section{Litteratur}

1. European Medicines Agency (EMA). Guideline on similar biological medicinal products containing monoclonal antibodies - non-clinical and clinical issues. http://ema.europa.eu/docs/en_GB/ document_library/Scientific_guideline/2012/06/ WC500128686.pdf (21.3.2014).

2. Danese S, Gomollon F. ECCO position statement: the use of biosimilar medicines in the treatment of inflammatory bowel disease (IBD). J Crohn's Colitis 2013; 7: 586-9.

3. Legemiddelinnkiøpssamarbeidet. LIS-TNF/ BIO-avtaler 2013. http://lisnorway.no/sider/ tekst.asp?side=64 (17.3.2014).

4. Legemiddelinnkjøpssamarbeidet. LIS-TNF-BIOanbefalinger-2014. http://lisnorway.no/lisnorway/ vedlegg/LIS-TNF-BIO-anbefalinger-2014.pdf (17.3.2014).

Mottatt 11.2.2014, første revisjon innsendt 4.3. 2014, godkjent 18.3.2014. Redaktør: Hanne Støre Valeur.

Publisert først på nett. 